\title{
NIST Outdoor Structure Separation Experiments (NOSSE): Preliminary Test Plan
}

Alexander Maranghides

Shonali Nazare

Eric Link

Matthew Bundy

Artur Chernovsky

Erik Johnsson

Kathryn Butler

Steven Hawks

Frank Bigelow

William (Ruddy) Mell

Anthony Bova

Derek McNamara

Tom Milac

Daniel Gorham

Faraz Hedayati

Bob Raymer

Frank Frievalt

William Walton

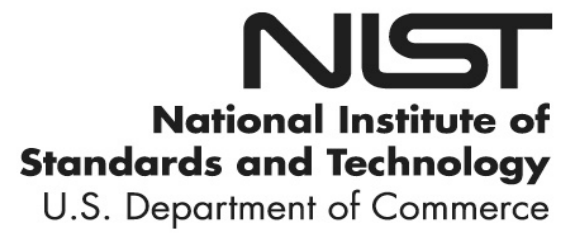


NIST Technical Note 2199

\title{
NIST Outdoor Structure Separation Experiments (NOSSE): Preliminary Test Plan
}

\author{
Alexander Maranghides, Shonali Nazare, Eric Link, \\ Matthew Bundy, Artur Chernovsky, Erik Johnsson, Kathryn Butler \\ Fire Research Division, Engineering Laboratory \\ National Institute of Standards and Technology \\ Steven Hawks, Frank Bigelow \\ Office of the State Fire Marshal
}

California Department of Forestry and Fire Protection

William (Ruddy) Mell, Anthony Bova, Derek McNamara, Tom Milac

United States Forest Service

Daniel Gorham, Faraz Hedayati

Insurance Institute for Businesses and Home Safety

Bob Raymer

California Building Industry Association

Frank Frievalt

Mammoth Lakes Fire Protection District

William Walton

University of Maryland

This publication is available free of charge from:

https://doi.org/10.6028/NIST.TN.2199

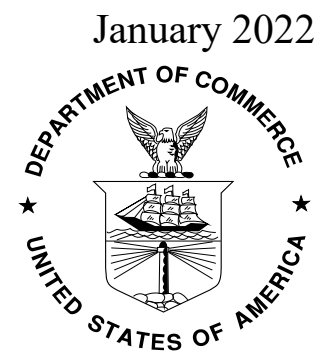

U.S. Department of Commerce

Gina M. Raimondo, Secretary

National Institute of Standards and Technology James K. Olthoff, Performing the Non-Exclusive Functions and Duties of the Under Secretary of Commerce for Standards and Technology \& Director, National Institute of Standards and Technology 
The policy of the National Institute of Standards and Technology is to use metric units in all its published materials. Because this report is intended for the U.S. building construction industry, which uses inch-pound units, it is more practical and less confusing to use inch-pound units, in some cases, rather than metric units.

However, in most cases, units are presented in both metric and the inch-pound system.

Certain commercial entities, equipment, or materials may be identified in this document in order to describe an experimental procedure or concept adequately. Such identification is not intended to imply recommendation or endorsement by the National Institute of Standards and Technology, nor is it intended to imply that the entities, materials, or equipment are necessarily the best available for the purpose.

National Institute of Standards and Technology Technical Note 2199

Natl. Inst. Stand. Technol. Tech. Note 2199, 28 pages (January 2022) CODEN: NTNOEF

This publication is available free of charge from:

https://doi.org/10.6028/NIST.TN.2199 


\begin{abstract}
The Structure Separation Project is a multi-phase project to assess structure-to-structure fire spread in Wildland-Urban Interface (WUI) communities. The project is divided into three phases with each phase assessing radiant and convective heat exposures from different sizes of sources. Phase 1 considers sheds from $1.39 \mathrm{~m}^{2}$ to $24.8 \mathrm{~m}^{2}\left(15 \mathrm{ft}^{2}\right.$ to $\left.267 \mathrm{ft}^{2}\right)$ as source structures while Phase 2 and Phase 3 will study heat exposures from auxiliary dwelling units [40.9 $\left.\mathrm{m}^{2}\left(440 \mathrm{ft}^{2}\right)\right]$ and single-family homes $92.90 \mathrm{~m}^{2}\left(1000 \mathrm{ft}^{2}\right)$, respectively.

This outdoor experimental series is an extension of the indoor shed burn experiments performed to measure heat release rates and mass loss rates of sheds at the National Fire Research Laboratory (NFRL). The outdoor full-scale shed burn experiments will be conducted in the presence of an artificially generated wind field. Varying sizes of sheds containing wood cribs (as fire source) will be used to generate typical radiative and convective heat exposures on a target structure (assembly of an exterior wall with a window and a roof to represent a single-story residential building). The spacing between the source and target structure will be varied to determine minimum structure separation distance (SSD), which is defined as the shortest distance between the source and the target structure to prevent flame spread. The minimum SSD for combustible (wood) and non-combustible (steel) sheds will be identified.
\end{abstract}

\title{
Key words
}

Community fire spread; fire convection; fire heat flux; fire radiation; sheds; structure separation distance; structure-to-structure fire spread; wind driven fires; wildland fire; wildland-urban interface. 


\section{Table of Contents}

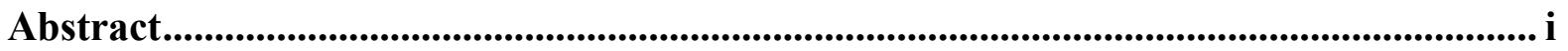

Table of Contents .............................................................................................................. ii

List of Tables .................................................................................................................

List of Figures................................................................................................................... iv

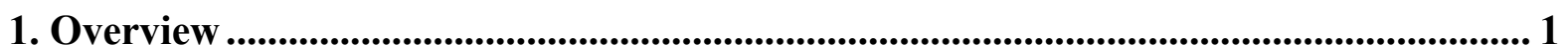

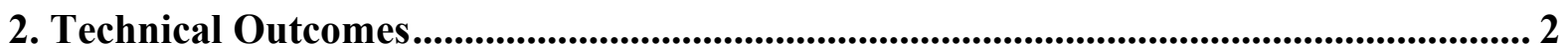

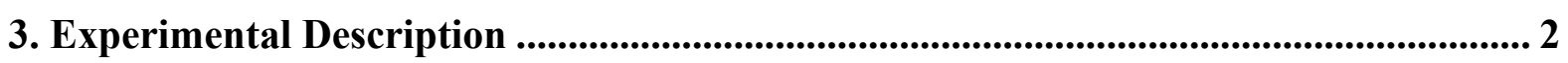

3.1. Wind Field Generation and Cold Flow Measurements ................................................. 2

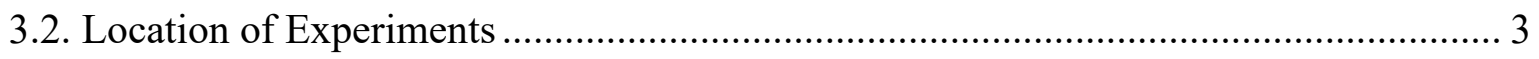

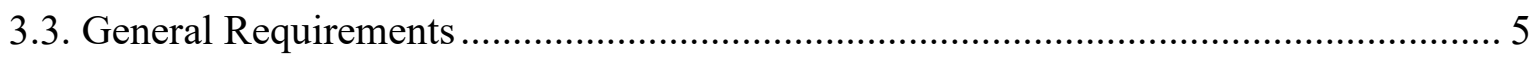

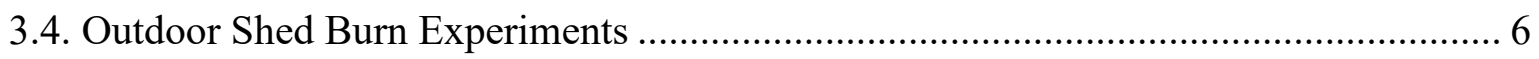

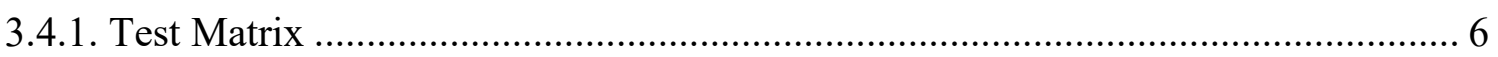

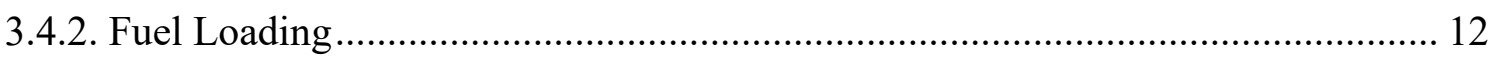

3.4.3. Instrumentation and Data Collection System ………...................................... 12

3.4.4. Target Structure Orientation .......................................................................... 16

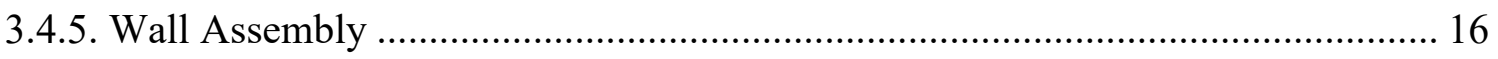

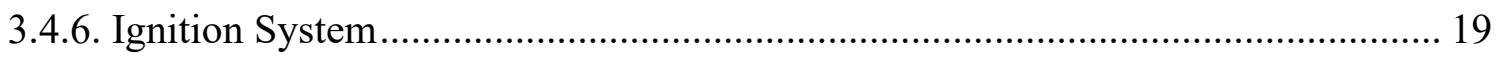

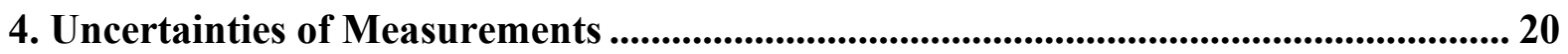

5. Data Management.......................................................................................................................... 21 


\section{List of Tables}

Table 1: Test Parameters for Outdoor Shed Burn Experiments. $(1 \mathrm{ft}=0.305 \mathrm{~m}) \ldots \ldots \ldots \ldots \ldots . .7$

Table 2: Possible Test Space for Outdoor Shed Burn Experiments. $(1 \mathrm{ft} .=0.305 \mathrm{~m}) \ldots \ldots \ldots \ldots$

Table 3: Sequence of Tests for Outdoor Shed Burn Experiments $(1 \mathrm{ft} .=0.305 \mathrm{~m}) \ldots \ldots \ldots \ldots \ldots$

Table 4: Shed Specifications for Outdoor Shed Burn Experiments $(1 \mathrm{ft}=0.305 \mathrm{~m}$, $1 \mathrm{lb}=0.453 \mathrm{~kg})$

Table 5: Fuel Loading Specifications for Different Source Structures. $(1 \mathrm{ft}=0.305 \mathrm{~m}$, $1 \mathrm{lb}=0.453 \mathrm{~kg})$

Table 6: Location and orientation of instrumentation with reference to the global origin (front center of the target structure) 


\section{List of Figures}

Figure 1: Photos of closets and very small sheds in common locations against the primary structure and near other vulnerabilities such as windows and combustible fencing. Photo Credits: NIST. 1

Figure 2: Configuration of bidirectional probes array .................................................. 3

Figure 3: Aerial view of NIST NFRL. Blue rectangle is $6 \mathrm{~m} \times 30 \mathrm{~m}(20 \mathrm{ft} \times 100 \mathrm{ft})$ and represents the maximum extent of the test area to be used. Imagery: Google, Landsat/ Copernicus. Overlays: NIST.

Figure 4: Approximate spacings among the wind machine, the flow straighteners, the bidirectional probes, the shed, and the target structure. $(1 \mathrm{ft}=0.305 \mathrm{~m})$

Figure 5: Typical experimental set-up for shed burn experiments (top: plan, bottom: side view $)$. $(1 \mathrm{ft}=0.305 \mathrm{~m})$

Figure 6: Test site and possible locations of sound level measurements. Imagery: Google, Landsat/Copernicus. Overlays: NIST. $(1 \mathrm{ft}=0.305 \mathrm{~m})$.

Figure 7: Photographs showing eave vents with (a) front and (b) rear TCs...................... 13

Figure 8: Test set-up and instrumentation plan for NOSSE. $(1 \mathrm{ft}=0.305 \mathrm{~m}) \ldots \ldots \ldots \ldots \ldots \ldots \ldots . \ldots \ldots$

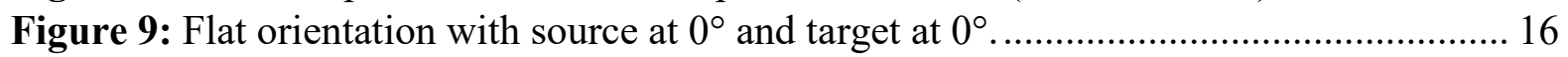

Figure 10: Schematic of target wall showing front and side view. $(1 \mathrm{ft}=0.305 \mathrm{~m}) \ldots \ldots \ldots \ldots . . .16$

Figure 11: Wall construction details for replaceable target structure with roof overhang. $(1 \mathrm{ft}=0.305 \mathrm{~m})$ 17

Figure 12: Eave height above ground level. $(1 \mathrm{ft}=0.305 \mathrm{~m})$. 


\section{Overview}

The NIST (National Institute of Standards and Technology) Outdoor Structure Separation Experiments (NOSSE) are part of the Structure Separation Experiments project to assess structure-to-structure fire spread for structures located in the Wildland-Urban Interface (WUI). This outdoor experimental series is an extension of the indoor shed burn experiments performed to measure heat release rates and mass loss rates at the National Fire Research Laboratory (NFRL). The primary objective of these outdoor shed burn experiments is to identify safe structure separation distance (SSD) to prevent fire spread in communities located within the Wildland-Urban Interface (WUI). These outdoor full-scale shed burn experiments will be conducted in the presence of an artificially generated wind field. Varying sizes of structures with varying wood crib fuel loadings (source of fire) will be used to generate typical radiative and convective heat exposures on a target structure (assembly of an exterior wall with a window and a roof to represent a single-story residential building). The maximum fire load of the source term will be less than $10 \mathrm{MW}$. The spacing between the source and target structures will be varied to determine minimum structure separation distance (SSD). SSD is defined as the shortest distance between the source and the target structure to prevent flame spread. The minimum SSD for combustible (wood) and noncombustible (steel) sheds with combustible contents will be identified.

The outcome of this experimental test series will provide minimum spacing requirements for the placement of Closets (C) and Very Small (VS) and Small (S) sheds in high-risk WUI communities. Currently, homeowners have a tendency to place these accessory structures with floor areas of less than $11 \mathrm{~m}^{2}\left(120 \mathrm{ft}^{2}\right)$ next to residential structures, as illustrated in Figure 1.

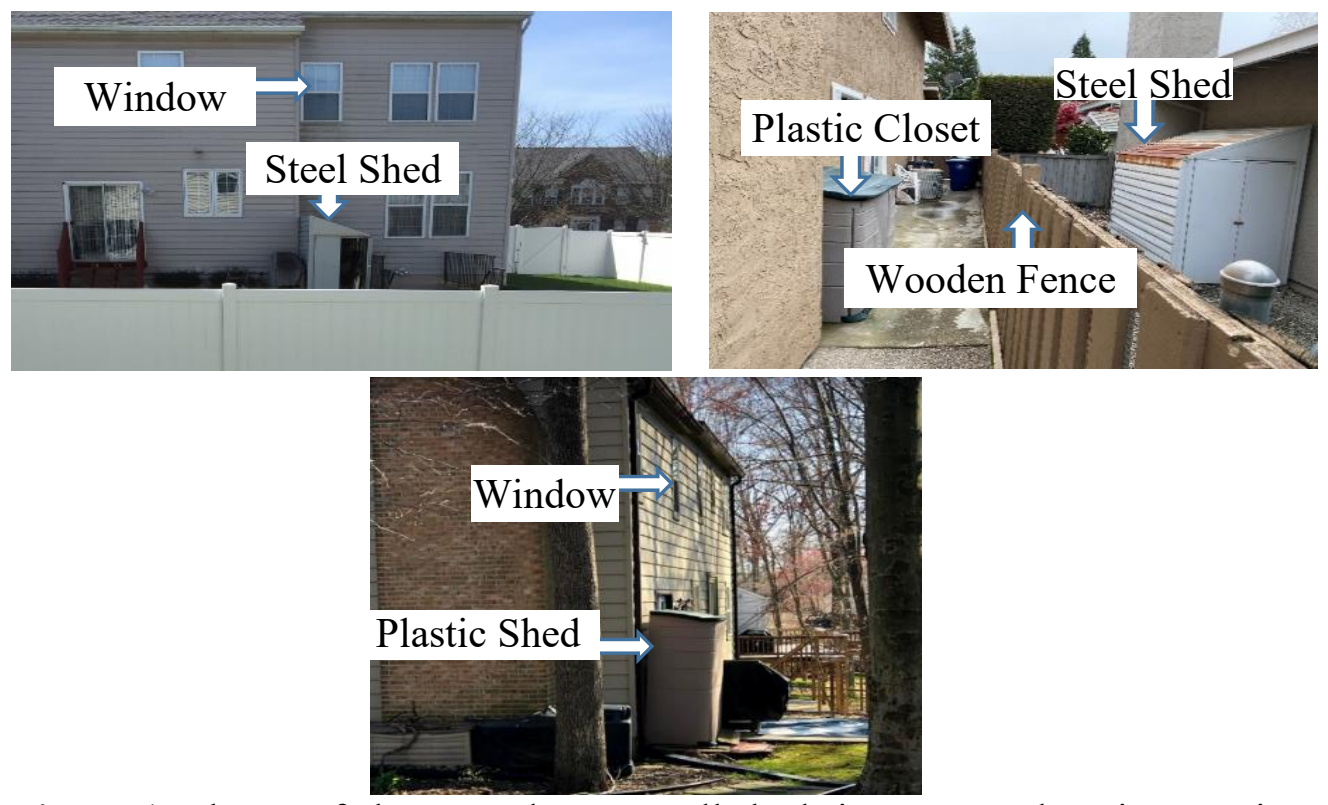

Figure 1: Photos of closets and very small sheds in common locations against the primary structure and near other vulnerabilities such as windows and combustible fencing. Photo Credits: NIST. 
Recent indoor shed burn experiments suggested that the radiant heat and flames from the burning wood closet could ignite the target structure (exterior wall-roof assembly). Fire spread on the roof and in the attic space was evident even with low fuel loadings and in the absence of wind ${ }^{1}$.

The proposed outdoor experimental series also aims at assessing the effects of wind on fire spread from accessory structures (sheds) to primary residential structures.

\section{Technical Outcomes}

The following technical outcomes are expected from the proposed experimental series:

- SSD for a combustible source structure (of three sizes: closet, very small shed, and small shed) and a non-combustible wall (target structure) built using California Chapter $7 \mathrm{~A}^{2}$ compliant materials.

- SSD for a non-combustible source structure (of three sizes: closet, very small shed, and small shed) and a non-combustible wall built using California Chapter 7A compliant materials.

- SSD for a combustible and non-combustible source structure and a combustible wall.

- Quantified heat exposures to the target structure from combustible and noncombustible source structures of varying sizes in the presence of wind.

Performance of the exterior wall assembly, window, attic vents, and eaves that are currently listed as California Chapter 7A compliant materials will be assessed. All experiments will be conducted on flat ground, therefore, any potential effects of topography on SSD will not be investigated. Additionally, potential effects of a corner or other complex structure (target) geometry on SSD will also not be assessed. Lastly, these experiments will assess SSDs for materials compliant with California Chapter 7A 2021 revision. Shortening or lengthening of the SSDs determined during this experimental series will, therefore, be the minimum SSDs, and additional provisions may be necessary to implement this guidance in the conditions that are not within the scope of this study.

\section{Experimental Description}

\subsection{Wind Field Generation and Cold Flow Measurements}

To study the effects of wind on the fire spread from a burning shed (source structure) to the target structure, a wind field will be generated using a dual wind machine. The wind machine will consist of two gasoline engines and propellers mounted on a trailer. A flow straightener consisting of three $1.22 \mathrm{~m} \times 1.44 \mathrm{~m}(4 \mathrm{ft} \times 8 \mathrm{ft})$ frames of aluminum honeycomb will be used to adjust the wind direction and to remove unwanted large-scale swirls in the wind field generated by the wind machine. The wind field directed towards the target structure will be

\footnotetext{
${ }^{1}$ NIST Indoor Structure Separation Experiments (NISSE), NIST TN 2195 in preparation,

${ }^{2}$ California Building Code-Chapter 7A-Materials and construction methods for exterior wildfire exposure. Available at https://up.codes/viewer/california/ca-building-code-2016/chapter/7A/sfm-materials-andconstruction-methods-for-exterior-wildfire-exposure\#7A
} 
characterized using an array of bidirectional probes shown in Figure 2. The flow will be measured in planes/cross-sections upstream from the source. The probe array will be moved back and forth to gather data across each plane. The wind flow will be measured for three different wind velocities including the wind velocity generated while the wind machine is running in an idle condition. The locations of the flow straightener and the bidirectional probes for the wind machine will be identified after the cold flow measurements. The ambient wind speed and direction will be measured using two sonic anemometers.

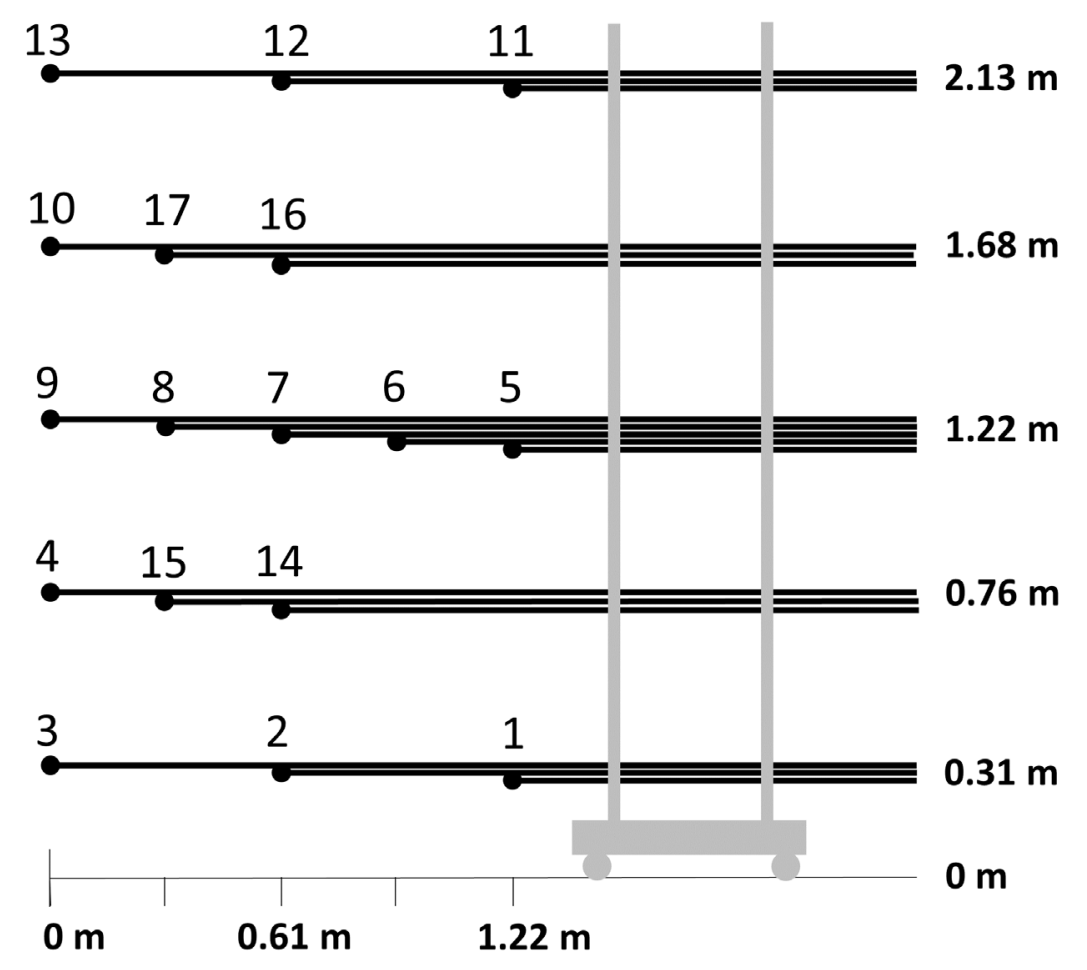

Figure 2: Configuration of bidirectional probes array

\subsection{Location of Experiments}

The location of all the outdoor experiments is shown in Figure 3. The test area is approximately $6 \mathrm{~m} \times 30 \mathrm{~m}(20 \mathrm{ft} \times 100 \mathrm{ft})$. Approximate spacings for the wind machine, the flow straighteners, the bidirectional probes, the shed, and the target structure are shown in Figure 4. Figure 5 shows a typical set-up for the shed burn experiments. 


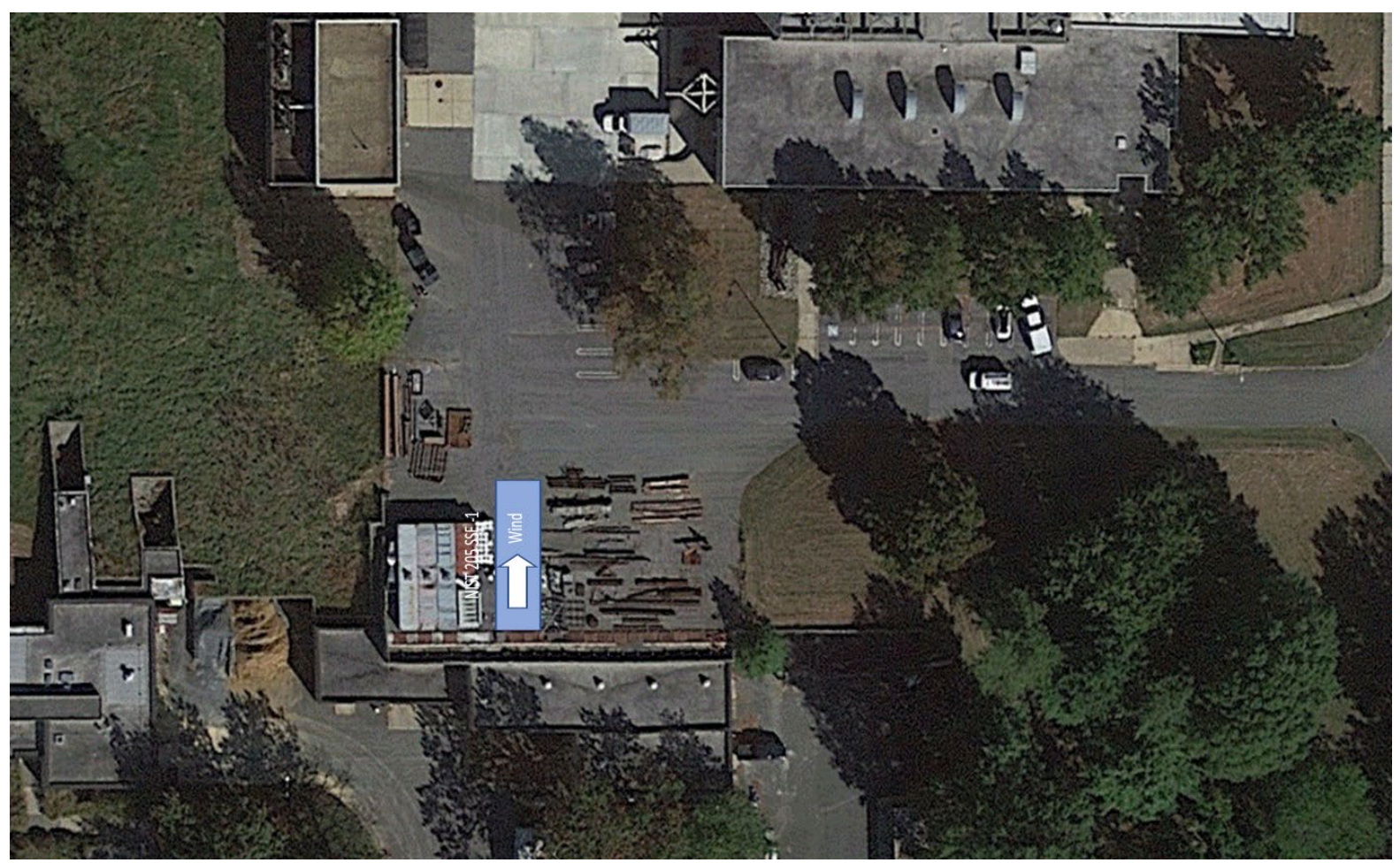

Figure 3: Aerial view of NIST NFRL. Blue rectangle is $6 \mathrm{~m} \times 30 \mathrm{~m}(20 \mathrm{ft} \times 100 \mathrm{ft})$ and represents the maximum extent of the test area to be used. Imagery: Google, Landsat/ Copernicus. Overlays: NIST.

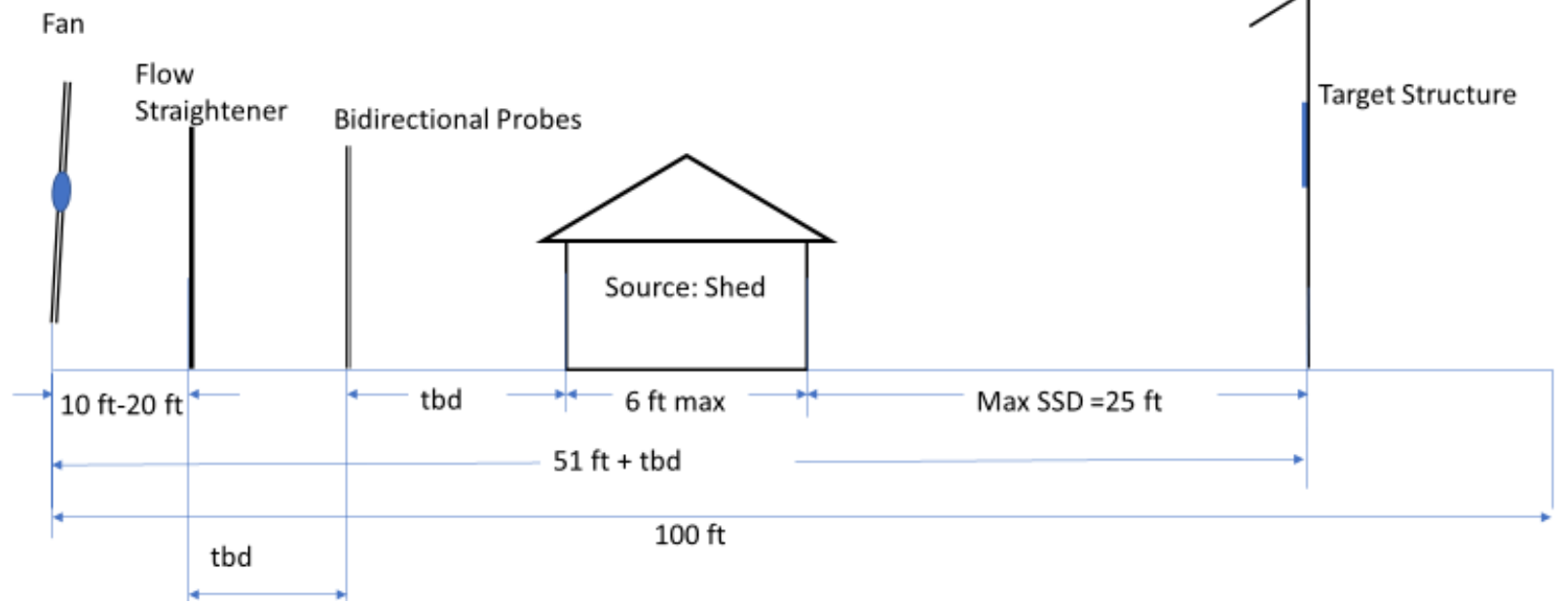

Figure 4: Approximate spacings among the wind machine, the flow straighteners, the bidirectional probes, the shed, and the target structure. $(1 \mathrm{ft}=0.305 \mathrm{~m})$ 


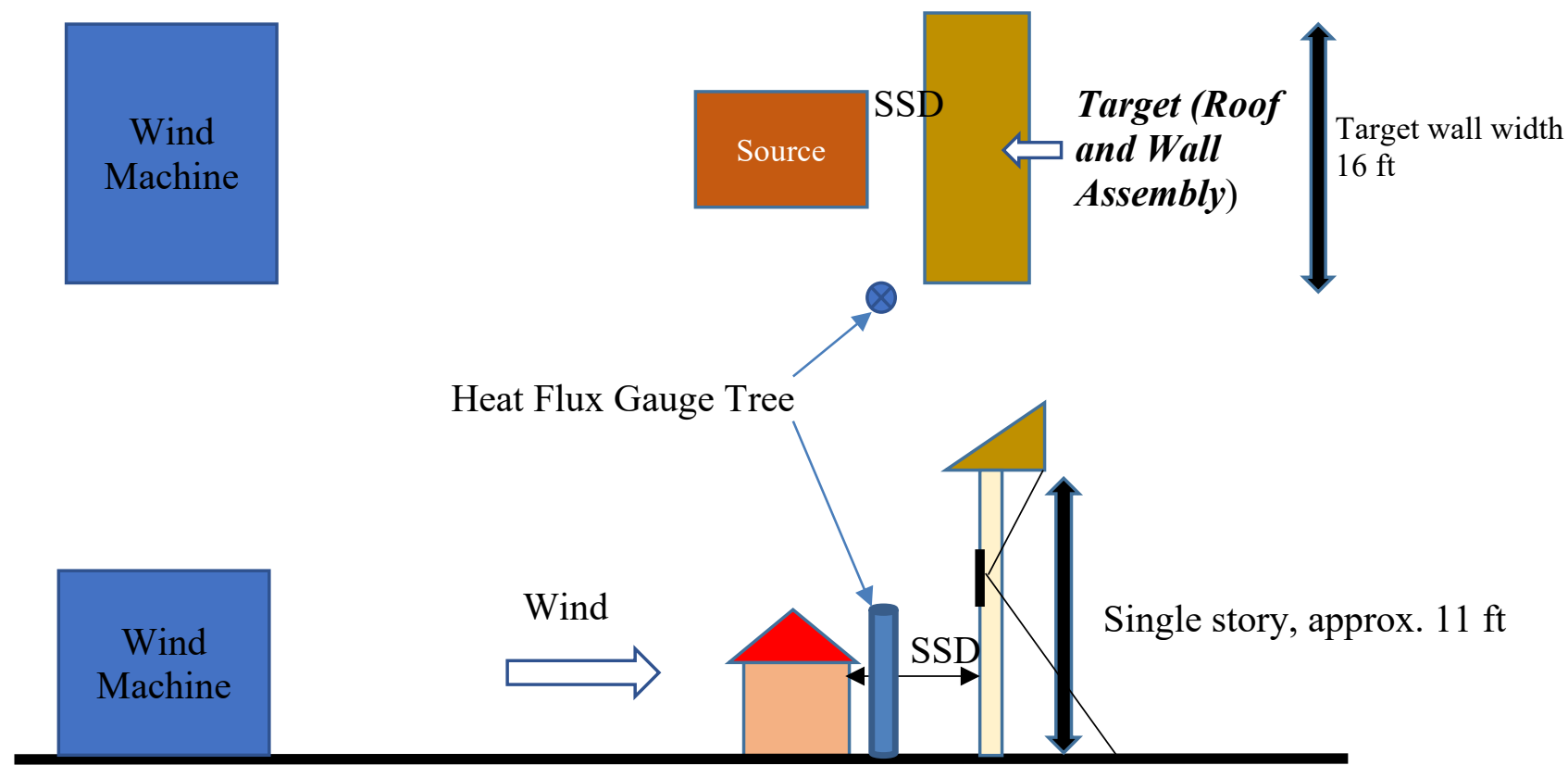

Figure 5: Typical experimental set-up for shed burn experiments (top: plan, bottom: side view). $(1 \mathrm{ft}=0.305 \mathrm{~m})$

\subsection{General Requirements}

A minimum of two personnel are required to be present during preparation and cleanup of experiments.

Tests will be performed early in the mornings (most probably at the first appearance of light) to minimize interference to the surrounding population and activities.

Weather conditions will be monitored, and the tests will only be performed on days when wind direction and wind speed is conducive to fire tests and on dry days (no precipitation in forecast from 5 am to noon). Tests will be conducted on days when SW to NW and SE to NE wind speed is less than $10 \mathrm{mph}$ and SW to SE wind speed less than $5 \mathrm{mph}$.

NIST Fire Department will be present during all the tests.

Sound levels at various places on the campus and nearer to the residential areas shown in Figure 6 will be assessed upon turning on the dual wind machine. 


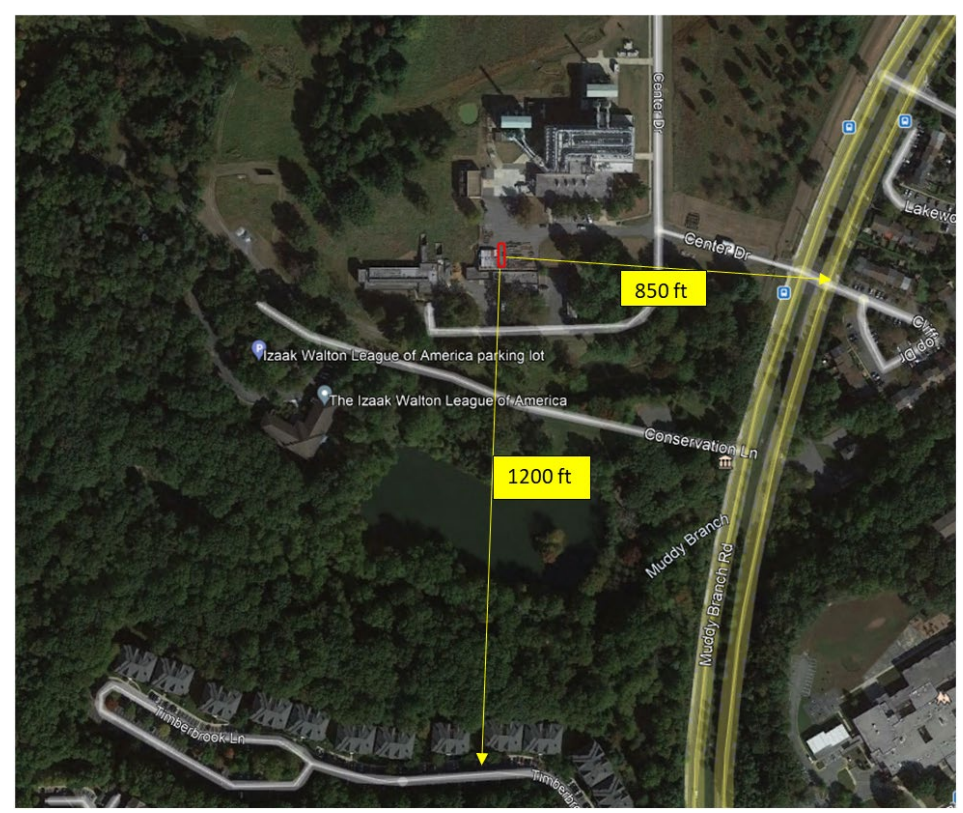

Figure 6: Test site and possible locations of sound level measurements. Imagery: Google, Landsat/Copernicus. Overlays: NIST. $(1 \mathrm{ft}=0.305 \mathrm{~m})$

Source structures up to $64 \mathrm{ft}^{2}$ floor area will be tested. Tentative testing period is from $1^{\text {st }}$ of September to $30^{\text {th }}$ of November 2021. An exclusion zone for staff and vehicles will be clearly marked to prevent approach from downwind.

\subsection{Outdoor Shed Burn Experiments}

The primary objective of these outdoor experiments is to determine safe SSD to prevent fire spread in the presence of wind for:

- various source sizes and fuel loadings,

- sources of different construction materials, and

- target structures both compliant and non-compliant with California Chapter 7A construction code ${ }^{3}$.

In the following sub-sections, the rationale for the experimental test matrix, the details of the fuel loading and sheds, and descriptions of the instrumentation and data collection system are provided.

\subsubsection{Test Matrix}

Based on the previous indoor shed burn experiments with no wind, it was found that a combustible wood closet with low fuel loading (two 1-A wood cribs ${ }^{4}$ ) and with zero SSD resulted in the ignition of the rafters and failure of the window and vent on the target structure. Significant damage and spalling of the exterior layer of cementitious board was also evident. For a non-combustible steel closet with high fuel loading (four 1-A wood cribs),

\footnotetext{
${ }^{3}$ Note: The test series did not include any fuels between the shed and the target structure.

${ }^{4}$ Note: See Section 3.3.2 for specifications of wood cribs.
} 
the thermal damage to the target structure was minimal with the shed door opening facing away from the target structure. However, when a very small steel shed (with six 1-A wood cribs) facing the target structure was tested with SSD of $1.5 \mathrm{~m}(5 \mathrm{ft})$, ignition of the rafters and failure of the window was noted. The observations from the indoor shed burn experiments provided guidance for the size of fire, approximate heat fluxes at given distances, and minimum SSD. The outcomes of the indoor shed burn test series provide guidance for selection of SSD for combustible and non-combustible sheds in the presence of wind. The test parameters for the outdoor shed burn experiments are listed in

Table 1, and the possible test space is listed in Table 2. Table 3 shows the sequence of tests for the outdoor shed burn experiments and the rationale for each experiment. The specifications of the commercially available sheds used for testing are provided in Table 4.

The test naming convention for the outdoor experiments is as follows: Outdoor (O) Material [Wood (W) and Steel (S)], Size [Closet (C), Very Small (VS), and Small (S)], Fuel Loading [high fuel loading (h) and low fuel loading (l)], Wind speed ${ }^{5}$ [w (mi/h)] - structure separation distance [SSD (ft)]. The letter " $\mathrm{R}$ " followed by a number at the end of the test name indicates a test replicate. For example, the first repeat for a very small wooden shed with high fuel loading $(\mathrm{h}), 8.9 \mathrm{~m} / \mathrm{s}(20 \mathrm{mi} / \mathrm{h})$ wind, and $3.04 \mathrm{~m}(10 \mathrm{ft}) \mathrm{SSD}$ will have test number O-WVSh20-10-R1.

Table 1: Test Parameters for Outdoor Shed Burn Experiments. $(1 \mathrm{ft}=0.305 \mathrm{~m})$

\begin{tabular}{|c|l|l|l|}
\hline $\begin{array}{c}\text { Source Structure } \\
\text { Construction }\end{array}$ & $\begin{array}{l}\text { Source Structure } \\
\text { Size }\end{array}$ & $\begin{array}{l}\text { Fuel } \\
\text { Loading }\end{array}$ & Wind speed \\
\hline $\begin{array}{c}\text { Combustible } \\
\text { (Wood) }\end{array}$ & $\begin{array}{c}\text { Closet }(3 \mathrm{ft} \times 5 \mathrm{ft}) \\
<75 \mathrm{ft}^{3}\end{array}$ & & \\
\cline { 2 - 2 } & $\begin{array}{c}\text { Very Small }(4 \mathrm{ft} \times \\
4 \mathrm{ft})<150 \mathrm{ft}^{3}\end{array}$ & High & Variable \\
\cline { 1 - 1 } $\begin{array}{c}\text { Non-combustible } \\
\text { (Steel) }\end{array}$ & $\begin{array}{c}\text { Small }(4 \mathrm{ft} \times 8 \mathrm{ft}) \\
<300 \mathrm{ft}^{3}\end{array}$ & & \\
\cline { 2 - 3 } & & \\
\hline
\end{tabular}

\footnotetext{
${ }^{5}$ To represent the worst case scenario, the wind speed will be determined by the wind machine setting required to tilt the flames from the source structure against the target structure..
} 
Table 2: Possible Test Space for Outdoor Shed Burn Experiments. $(1 \mathrm{ft} .=0.305 \mathrm{~m})$

\begin{tabular}{|c|c|c|c|c|c|c|}
\hline $\begin{array}{l}\text { Serial } \\
\text { Number }\end{array}$ & Test ID & $\begin{array}{l}\text { Source } \\
\text { Construction }\end{array}$ & $\begin{array}{l}\text { Source } \\
\text { Size }\end{array}$ & $\begin{array}{l}\text { Fuel } \\
\text { Loading } \\
\text { (1-A cribs) }\end{array}$ & SSD & Wind \\
\hline 1 & O-WChw-10 & \multirow{8}{*}{ Wood } & Closet & 4 & 10 & Yes \\
\hline 2 & O-WChw-10-R1 & & Closet & 4 & 10 & Yes \\
\hline 3 & O-WVSh0-10 & & VS & 6 & 10 & No \\
\hline 4 & O-WVShw-10 & & VS & 6 & 10 & Yes \\
\hline 5 & O-WShw-20 & & Small & 12 & 20 & Yes \\
\hline 6 & O-WShw-20-R1 & & Small & 12 & 20 & Yes \\
\hline 7 & O-WVShw-10-R1 & & VS & 12 & 10 & Yes \\
\hline 8 & Test \#7+XXft & & VS & 12 & $\begin{array}{l}10+ \\
\mathrm{XX} \mathrm{ft}\end{array}$ & Yes \\
\hline 9 & O-SChw-5 & \multirow{8}{*}{ Steel } & Closet & 4 & 5 & Yes \\
\hline 10 & O-SChw-10 & & Closet & 4 & 10 & Yes \\
\hline 11 & O-SVSh0-10 & & VS & 6 & 10 & No \\
\hline 12 & O-SVShw-10 & & VS & 6 & 10 & Yes \\
\hline 13 & O-SShw-15 & & Small & 12 & 15 & Yes \\
\hline 14 & O-SShw-15-R1 & & Small & 12 & $15 / 20$ & Yes \\
\hline 15 & TBD & & & & & Yes \\
\hline 16 & TBD & & & & & Yes \\
\hline
\end{tabular}


Table 3: Sequence of Tests for Outdoor Shed Burn Experiments $(1 \mathrm{ft} .=0.305 \mathrm{~m})$

\begin{tabular}{|c|c|c|}
\hline Test \# & Test ID & Comments \\
\hline 3 & O-WVSh0-10 & $\begin{array}{l}\text { Determine SSD for VS combustible shed in } \\
\text { absence of wind }\end{array}$ \\
\hline 11 & O-SVSh0-10 & $\begin{array}{l}\text { Determine SSD for VS non-combustible shed } \\
\text { in absence of wind }\end{array}$ \\
\hline 4 & O-WVShw-10 & $\begin{array}{l}\text { Determine SSD for VS combustible shed in } \\
\text { presence of wind }\end{array}$ \\
\hline 12 & O-SVShw-10 & $\begin{array}{l}\text { Determine SSD for VS non-combustible shed } \\
\text { in presence of wind }\end{array}$ \\
\hline 9 & O-SChw-5 & $\begin{array}{l}\text { Determine SSD for non-combustible closet } \\
\text { shed in presence of wind }\end{array}$ \\
\hline 1 & O-WChw-10 & $\begin{array}{l}\text { Determine SSD for combustible closet shed in } \\
\text { presence of wind }\end{array}$ \\
\hline 13 & O-SShw-15 & $\begin{array}{l}\text { Determine SSD for Small non-combustible } \\
\text { shed in presence of wind }\end{array}$ \\
\hline 5 & O-WShw-20 & $\begin{array}{l}\text { Determine SSD for Small combustible shed in } \\
\text { presence of wind }\end{array}$ \\
\hline 6 & O-WShw-20-R1 & Establish reproducibility of failure \\
\hline 14 & O-SShw-15-R1 & Establish reproducibility of failure \\
\hline 7 & O-WVShw-10-R1 & Establish reproducibility of failure \\
\hline 2 & TBD & Based on findings of tests listed above \\
\hline 8 & TBD & Based on findings of tests listed above \\
\hline 10 & TBD & Based on findings of tests listed above \\
\hline 16 & TBD & Based on findings of tests listed above \\
\hline
\end{tabular}


Table 4: Shed Specifications for Outdoor Shed Burn Experiments $(1 \mathrm{ft}=0.305 \mathrm{~m}, 1 \mathrm{lb}=0.453 \mathrm{~kg})$

\begin{tabular}{|c|c|c|c|c|c|c|}
\hline $\begin{array}{l}\text { Wood } \\
\text { Sheds } \\
\end{array}$ & Examples & $\begin{array}{c}\text { Size } \\
\mathbf{D} \times \mathbf{W} \times \mathbf{H}, \mathbf{f t} \\
\end{array}$ & $\begin{array}{c}\text { Capacity, } \\
\mathrm{ft}^{3} \\
\end{array}$ & $\begin{array}{c}\text { Door } \\
\mathbf{W} \times \mathbf{H}, \mathbf{f t}\end{array}$ & $\begin{array}{c}\text { Weight, } \\
\text { lb }\end{array}$ & Notes \\
\hline $\begin{array}{c}\text { Closet } \\
3 \mathrm{ft} \times 5 \mathrm{ft}\end{array}$ & Link & $2.1 \times 5 \times 4$ & 42 & $5.0 \times 3.9$ & 99 & $\begin{array}{l}\text { Double door } \\
\text { Roof material: wood } \\
\text { Construction material: Cypress wood } \\
\text { Floor: No } \\
\text { Vents: No }\end{array}$ \\
\hline $\begin{array}{c}\text { Very small } \\
4 \mathrm{ft} \times 6 \mathrm{ft}\end{array}$ & Link & $3 \times 6 \times 5.4$ & 97.2 & $5.0 \times 5.2$ & 172 & $\begin{array}{l}\text { Double door } \\
\text { Roof material: wood } \\
\text { Construction material: Cypress wood } \\
\text { Floor: not specified } \\
\text { Vents: No }\end{array}$ \\
\hline $\begin{array}{c}\text { Small } \\
4 \mathrm{ft} \times 8 \mathrm{ft}\end{array}$ & Link & $7.4 \times 7.6 \times 7.6$ & 429 & $4.6 \times 5.8$ & 621 & $\begin{array}{l}\text { Double door } \\
\text { Roof material: wooden shingles } \\
\text { Construction material: Engineered wood } \\
\text { Floor: No } \\
\text { Vents: No } \\
\text { Window: } 1\end{array}$ \\
\hline
\end{tabular}


Table 4 continued.

\begin{tabular}{|c|c|c|c|c|c|c|}
\hline $\begin{array}{c}\text { Steel } \\
\text { Sheds }\end{array}$ & Examples & $\begin{array}{c}\text { Size } \\
D \times W \times H, f t\end{array}$ & $\begin{array}{c}\text { Capacity, } \\
\mathrm{ft}^{3} \\
\end{array}$ & $\begin{array}{c}\text { Door } \\
\mathbf{W} \times \mathbf{H}, \mathbf{f t}\end{array}$ & $\begin{array}{l}\text { Weight, } \\
\text { lb }\end{array}$ & Notes \\
\hline $\begin{array}{c}\text { Closet } \\
3 \mathrm{ft} \times 5 \mathrm{ft}\end{array}$ & Link & $2.9 \times 5 \times 5.8$ & 84.1 & $5 \times 5$ & 93 & $\begin{array}{l}\text { Double door + Lid } \\
\text { Roof material: Steel } \\
\text { Construction material: Galvanized } \\
\text { steel } \\
\text { Floor: not specified }\end{array}$ \\
\hline $\begin{array}{c}\text { Very } \\
\text { Small } \\
4 \mathrm{ft} \times 4 \mathrm{ft}\end{array}$ & $\underline{\text { Link }}$ & $5 \times 6 \times 6.8$ & 95.2 & $5.7 \times 4.1$ & 163 & $\begin{array}{l}\text { Single door } \\
\text { Roof material: Steel } \\
\text { Construction material: Galvanized } \\
\text { steel } \\
\text { Floor: not included } \\
\text { Vents: No }\end{array}$ \\
\hline $\begin{array}{c}\text { Small } \\
4 \mathrm{ft} \times 8 \mathrm{ft}\end{array}$ & $\underline{\text { Link }}$ & $7.9 \times 5.9 \times 7.5$ & 287 & $5.2 \times 4.4$ & 250 & $\begin{array}{l}\text { Double door } \\
\text { Roof material: Steel } \\
\text { Construction material: Galvanized } \\
\text { steel } \\
\text { Floor: not included } \\
\text { Vents: } 2\end{array}$ \\
\hline
\end{tabular}




\subsubsection{Fuel Loading}

Wood cribs based on ANSI/UL711, ${ }^{6}$ design will be used. Size 1-A cribs (12 layers of 6 members with approximate dimensions of 1.5 inch $\times 1.5$ inch $\times 20$ inches $(38 \mathrm{~mm} \times 38 \mathrm{~mm}$ $\times 500 \mathrm{~mm}$ )) will be placed within the source structures (closet, very small and small sheds) to simulate high fuel loadings in storage sheds. The approximate dimensions of the 1-A crib will be 20 inches $\times 20$ inches $\times 18$ inches $(500 \mathrm{~mm} \times 500 \mathrm{~mm} \times 456 \mathrm{~mm})$ for a given spacing of 2 inches $(54 \mathrm{~mm})$ between two members. Average mass of 1 -A crib is $19.36 \mathrm{~kg} \pm 0.8 \mathrm{~kg}^{7}$. The moisture content of the wood cribs varies between $5 \%$ to $7 \%$.

The fuel loading specifications in terms of the number of wood cribs, total heat output, and total mass of wood cribs are provided in Table 5. The total mass of fuel load is calculated based on pine wood with a density of $500 \mathrm{~kg} / \mathrm{m}^{3}$. The estimated heat output of the fuel loading is calculated from the basis that heat released from combustion of a unit mass of pyrolysis products for pine wood is approximately $19.2 \mathrm{MJ} / \mathrm{kg}$ and that the burning rate of the crib is controlled by the internal surface and not restricted by the porosity of the crib. ${ }^{8}$

Table 5: Fuel Loading Specifications for Different Source Structures. $(1 \mathrm{ft}=0.305 \mathrm{~m}$, $1 \mathrm{lb}=0.453 \mathrm{~kg}$ )

\begin{tabular}{|l|l|l|l|}
\hline \multirow{2}{*}{ Source Size } & \multicolumn{3}{|c|}{ Fuel Loading Specifications } \\
\cline { 2 - 4 } & $\mathrm{n} \times 1-\mathrm{A}$ & $\begin{array}{l}\text { Peak heat release } \\
\text { rate }(\text { PHRR) } \\
\text { MW }\end{array}$ & Mass, lbs $(\mathrm{kg})$ \\
\hline Closet $(3 \mathrm{ft} \times 5 \mathrm{ft}), 15 \mathrm{ft}^{2}$ & $4 \times 1-\mathrm{A}$ & 1.16 & $229(104)$ \\
\hline Very Small $(3 \mathrm{ft} \times 6 \mathrm{ft}), 18 \mathrm{ft}^{2}$ & $6 \times 1-\mathrm{A}$ & 1.74 & $344(156)$ \\
\hline Small $(4 \mathrm{ft} \times 8 \mathrm{ft}), 32 \mathrm{ft}^{2}$ & $12 \times 1-\mathrm{A}$ & 3.49 & $688(312)$ \\
\hline
\end{tabular}

\subsubsection{Instrumentation and Data Collection System}

A total of six water-cooled Schmidt-Boelter heat flux gauges will be used to measure the combined radiative and convective heat fluxes. Four heat flux gauges (HFG1, HFG2, HFG3, and HFG4) will be located in the eaves (roof rafter bays) of the target structure as marked in Figure 8. The heat flux gauges in the eaves will be facing the source structure. HFG5 and HFG6 will be mounted on a tree at heights of $1 \mathrm{~m}(3.2 \mathrm{ft})$ and $3 \mathrm{~m}(9.8 \mathrm{ft})$, respectively, above the ground. The heat flux gauge tree will be placed $3 \mathrm{~m}(9.8 \mathrm{ft})$ away from the center line and at the mid-point between the target wall and the front of the shed with gauges facing

${ }^{6}$ ANSI/UL 711, Standard for Rating and Fire Testing of Fire Extinguishers, 2013.

${ }^{7}$ Reported uncertainty is $\pm 2 \sigma$, where $\sigma$ is the standard deviation.

${ }^{8}$ Walton WD. Suppression of Wood Crib Fires with Sprinkler Sprays: Test Results. NBSIR 88-3696, January 1988. 
west. One Type-K thermocouple will be placed next to each of the heat flux gauges in the rafter bays.

Additionally, three thermocouples will be placed near the vent (see Figure 7) to measure air temperatures at the front and back of the vent, and of the plywood at the vent.
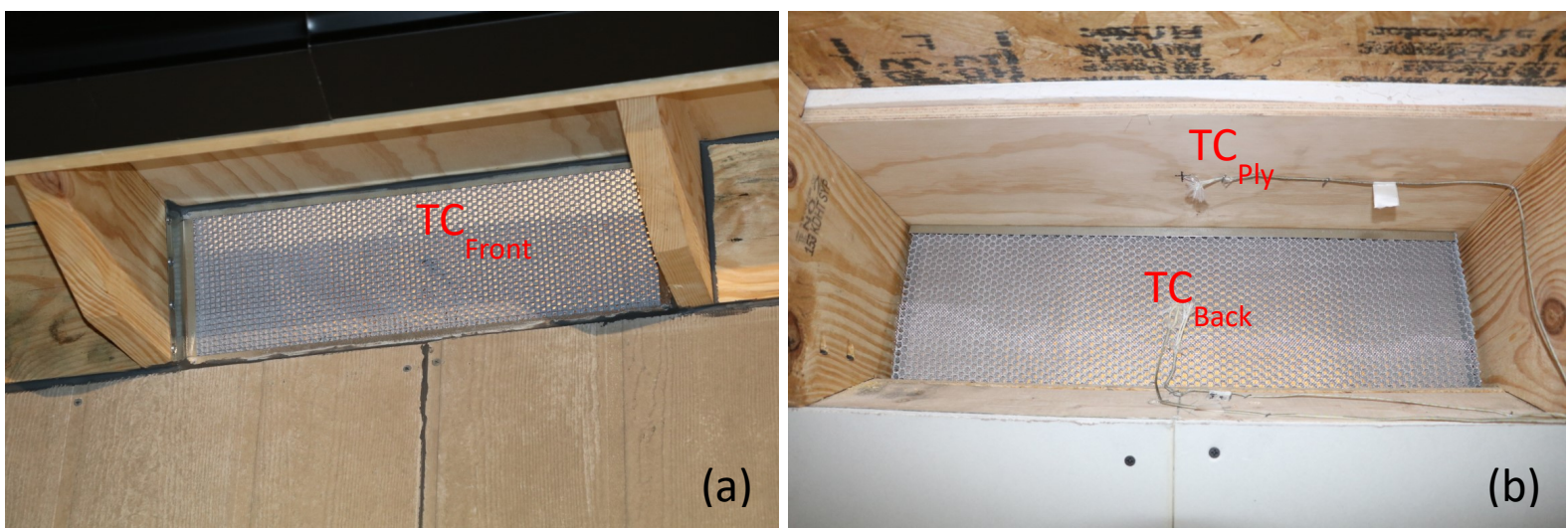

Figure 7: Photographs showing eave vents with (a) front and (b) rear TCs.

Two anemometers, placed nominally at a height of $1.83 \mathrm{~m}(6 \mathrm{ft})$ above the ground, will be used to monitor ambient wind speed and direction while an array of bidirectional probes will be used to characterize the wind field from the wind machine.

Digital video cameras will be used to record the fire events, and digital still photographs will be taken before and throughout the testing period. The locations of the video cameras are also marked in Figure 8. Not shown in Figure 8 is the Camera 5 under the roof, facing the eaves and a camera on the wind machine console to record the revolutions per minute (rpm) of the wind machine.

The locations of the instrumentation are provided in Table 6. 


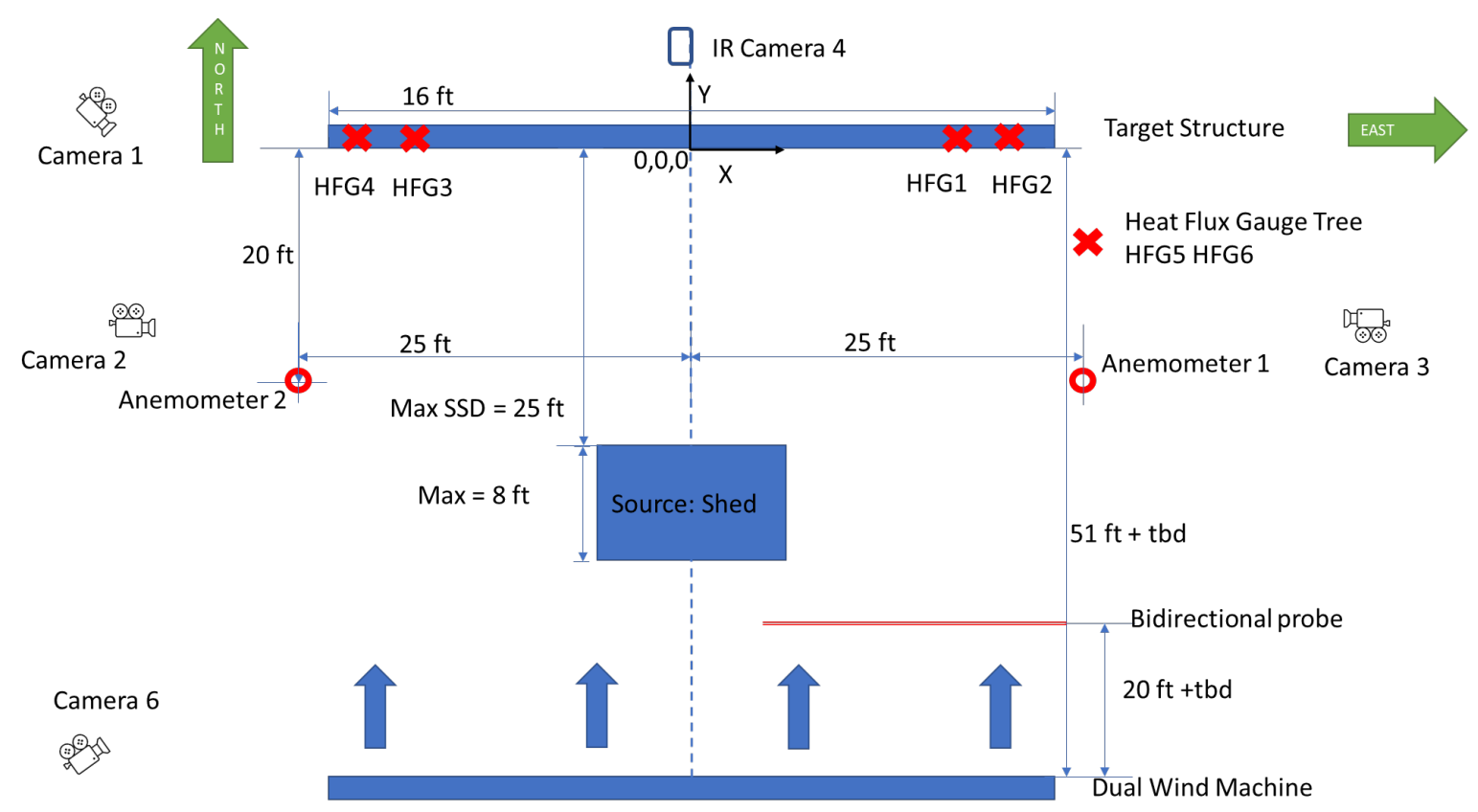

Figure 8: Test set-up and instrumentation plan for NOSSE. $(1 \mathrm{ft}=0.305 \mathrm{~m})$

A National Instruments data acquisition (DAQ) system using LabVIEW software will be used to sample the output from the heat flux sensors, thermocouples, anemometers, and the bidirectional probes at a sampling frequency of $1 \mathrm{~Hz}$. 
Table 6: Location and orientation of instrumentation with reference to the global origin (front center of the target structure)

\begin{tabular}{|l|l|l|l|l|l|}
\hline Device & ID & $\begin{array}{l}\text { X East+ } \\
(\mathbf{c m})\end{array}$ & $\begin{array}{l}\text { Y North+ } \\
(\mathbf{c m})\end{array}$ & $\begin{array}{l}\text { Z Up } \\
(\mathbf{c m})\end{array}$ & Orientation \\
\hline Heat flux gauge & HFG1 & 122 & 0 & 340 & Facing target wall \\
\hline Heat flux gauge & HFG2 & 183 & 0 & 340 & Facing target wall \\
\hline Heat flux gauge & HFG3 & -122 & 0 & 340 & Facing target wall \\
\hline Heat flux gauge & HFG4 & -183 & 0 & 340 & Facing target wall \\
\hline Heat flux gauge & HFG5 & -500 & -152 & 100 & $\begin{array}{l}\text { Facing plume between } \\
\text { shed and target wall }\end{array}$ \\
\hline Heat flux gauge & HFG6 & -500 & -152 & 300 & \\
\hline Thermocouple & TCventF & -4 & 0 & 416 & - \\
\hline Thermocouple & TCventR & 0 & 0 & 416 & - \\
\hline Thermocouple & TCply & 10 & 0 & 427 & - \\
\hline Thermocouple & TCeave1 & 122 & 0 & 340 & - \\
\hline Thermocouple & TCeave2 & 183 & 0 & 340 & - \\
\hline Thermocouple & TCeave3 & -122 & 0 & 340 & - \\
\hline Thermocouple & TCeave4 & -183 & 0 & 340 & - \\
\hline Anemometer & Anemometer 1 & 762 & -609 & 183 & - \\
\hline Anemometer & Anemometer 2 & -760 & -609 & 183 & - \\
\hline HDMI Camera & Camera 1 & -747 & 480 & 115 & $\begin{array}{l}\text { Rear northwest } \\
\text { (facing shed) }\end{array}$ \\
\hline HDMI Camera & Camera 2 & -716 & -343 & 118 & $\begin{array}{l}\text { Side west } \\
\text { (facing shed) }\end{array}$ \\
\hline HDMI Camera & Camera 3 & 924 & -610 & 145 & $\begin{array}{l}\text { Side east } \\
\text { (facing shed) }\end{array}$ \\
\hline IR Camera & Camera 4 & 0 & -633 & 38 & Facing target wall rear \\
\hline Web Camera & Camera 5 & 0 & 0 & 0 & Facing up toward eave \\
\hline Site Camera & Camera 6 & 762 & -1128 & 396 & Facing target wall \\
\hline
\end{tabular}

The data acquisition system control program will be equipped with event markers to record significant failure events. The following events will be marked during the experiment:

1. Ignition of heptane

2. Flames protruding from the shed

3. Shed collapse

4. Window front pane breakage

5. Window failure (hot gases or flames through window opening)

6. Smoldering of rafters

7. Rafter ignition (flaming)

8. Vent intumescence

9. Shed suppression

10. Roof suppression

11. Fire out

To track the progress of an experiment, a digital timer will be used. The timer will be started with the ignition of the wood cribs. A coordinate system with the origin at the front center of 
the target structure will be used to identify the locations of the instrumentation in the test setup.

\subsubsection{Target Structure Orientation}

The orientation of the target structure with respect to the shed source is shown in Figure 9. The source structure opening will always face the target structure.

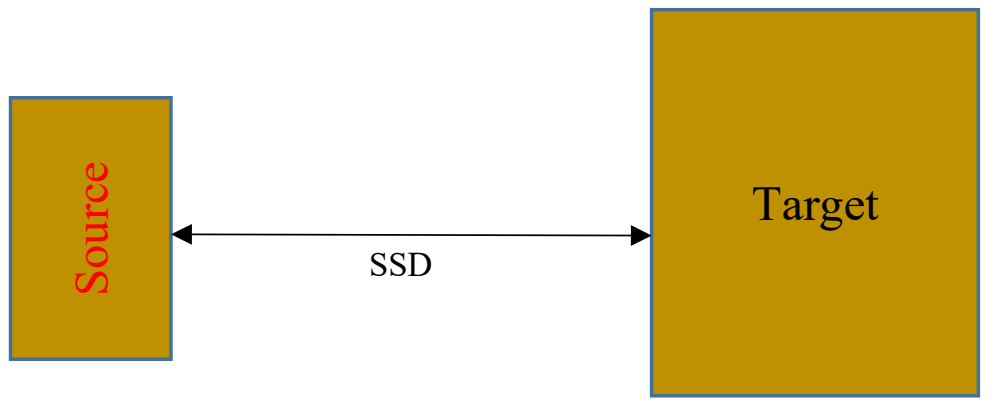

Figure 9: Flat orientation with source at $0^{\circ}$ and target at $0^{\circ}$.

\subsubsection{Wall Assembly}

A front and side view of the target wall with nominal dimensions is shown in Figure 10 below. The target wall has two components: 1) non-replaceable and 2) replaceable.

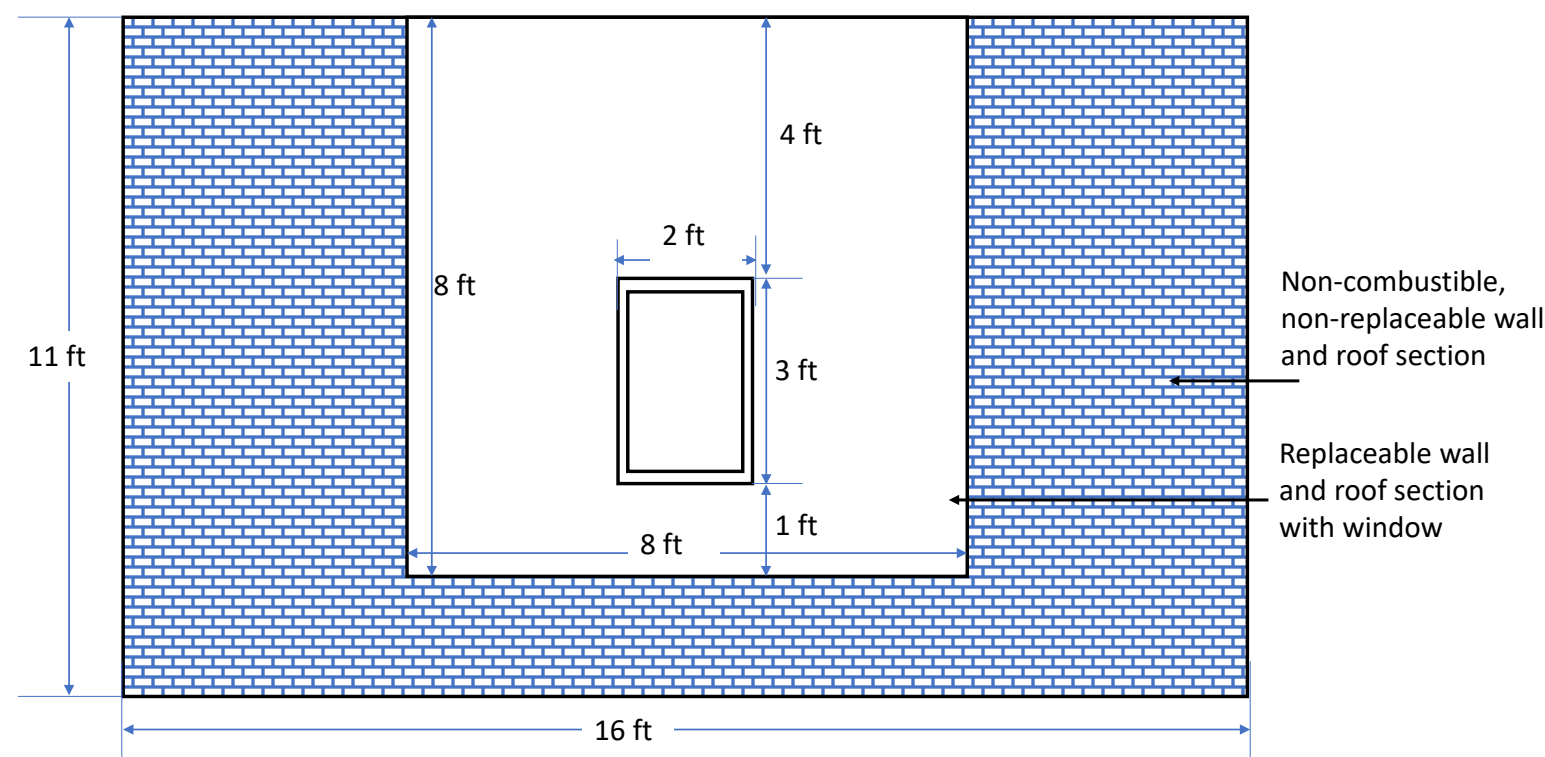

Figure 10: Schematic of target wall showing front and side view. $(1 \mathrm{ft}=0.305 \mathrm{~m})$

A schematic of the replaceable wall assembly with layers of construction is shown in Figure 11. The wall construction comprises the following layers (from interior to exterior):

- $5 / 8 "(16 \mathrm{~mm})$ drywall (1 layer in the interior) 
- 2 " $\times 4$ " studs [nominal - actual dimensions: $1.5 " \times 3.5 "(38 \mathrm{~mm} \times 89 \mathrm{~mm})$ ]

- 1 " $(2.5 \mathrm{~cm})$ mineral fiber insulation

- 7/16" (11 mm) Oriented Strand Board (OSB) sheathing

- 5/16" (8 mm) Fiber Cement Panel Siding

The materials for the target wall construction will be selected from the materials listed on California Building Materials listing website ${ }^{9}$.

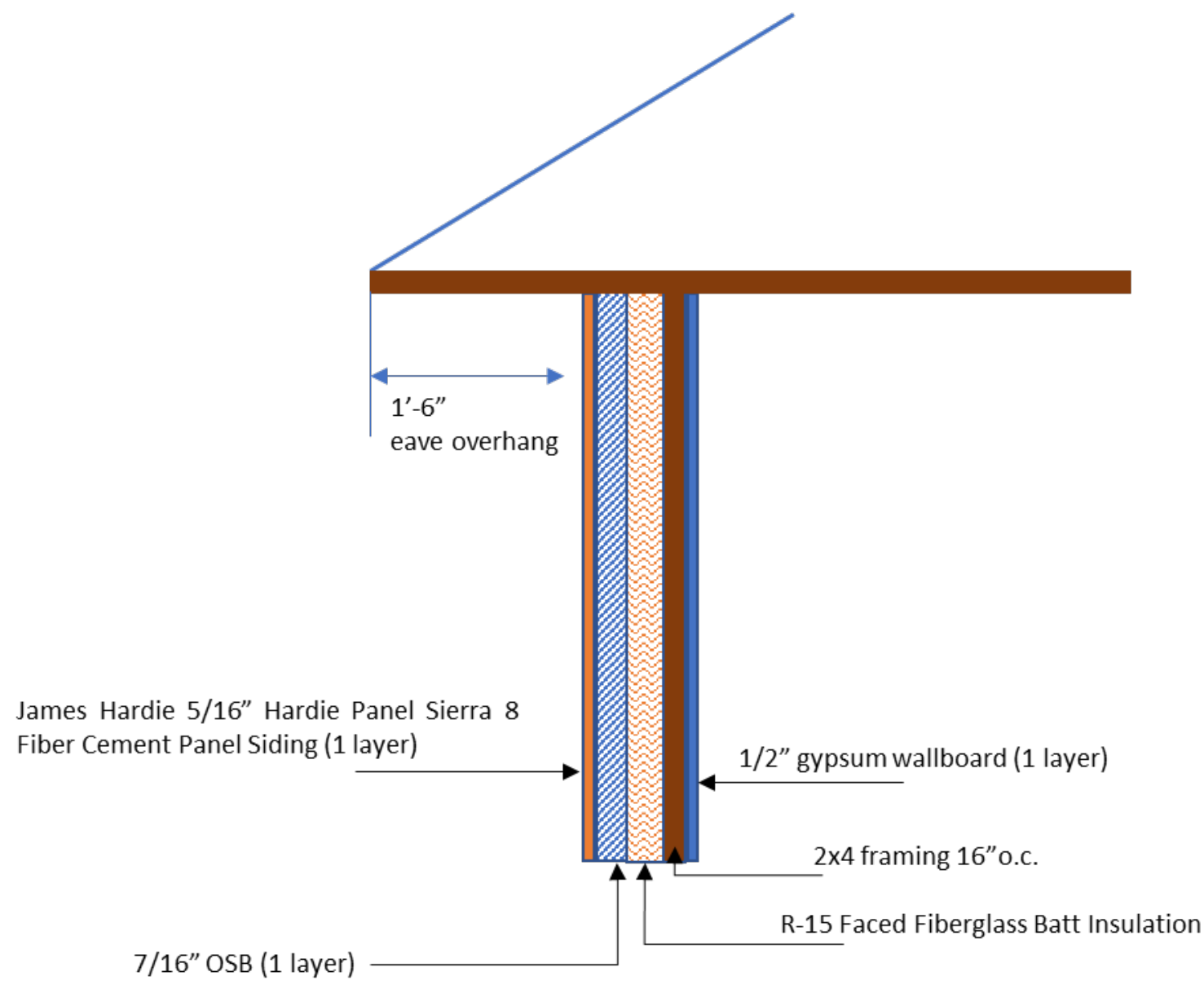

Figure 11: Wall construction details for replaceable target structure with roof overhang. $(1 \mathrm{ft}=0.305 \mathrm{~m})$

\section{Roof}

The roof will be built in compliance with California Chapter 7A requirements. Class A asphalt shingles will be used on 24" $(61 \mathrm{~cm})$ o.c. (over the center) rafters

\footnotetext{
${ }^{9}$ Welcome to BML Search Building Materials Listing (ca.gov)
} 
https://www.gaf.com/en-us/products/royal-sovereign

Color/Finish: Silver Lining

Roof underlayment with Class A fire rating (UL 790) will be used.

https://www.homedepot.com/p/GAF-Tiger-Paw-1000-sq-ft-Premium-Synthetic-Roofing-

Underlayment-Roll-0980/206885977

Gutters

https://www.homedepot.com/p/Spectra-Metals-6-in-x-8-ft-K-Style-Black-Aluminum-Gutter$\underline{6 \mathrm{KBK} 8 / 206305103}$

Drip Edge Flashing

https://www.homedepot.com/p/Amerimax-Home-Products-F5M-2-33-in-x-1-5-in-x-10-ftAluminum-Black-Drip-Edge-Flashing-5564535120/203484742

Eave

An open eave construction with an eave overhang distance of 18 " $(46 \mathrm{~cm})$ will be used. The eave height of 11' (3.35 m) AGL (Above Ground Level) assumes 9' (2.74 m) ceilings and a crawlspace as shown in Figure 12 .

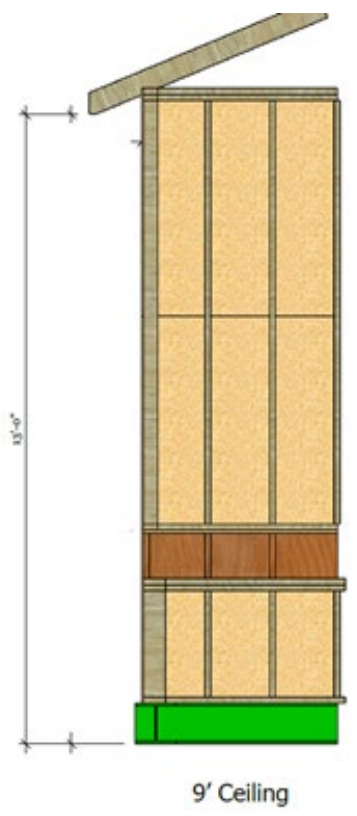

Figure 12: Eave height above ground level. $(1 \mathrm{ft}=0.305 \mathrm{~m})$ 


\section{Vents}

Fire resistant eave vents with intumescent coating will be used. These eave vents are generally recommended for residential construction in WUI areas. Vulcan eave vents with Reserve Tabs VE7522RT and nominal dimensions of 7.5" $\times 22 "(19.1 \mathrm{~cm} \times 55.9 \mathrm{~cm}$ will be used. https://www.vulcanvents.com/eave-vents/

\section{Window}

A tempered glass (front pane) window will be used.

https://www.homedepot.com/p/Ply-Gem-35-5-in-X-35-5-in-Classic-Active-Left-HandHPSC-Tempered-Glass-Horizontal-Sliding-Vinyl-Window-White-Exterior-CLASSIC-SL36X36-HPSC-TEMPERED-WUI/315857409

\subsubsection{Ignition System}

Wood cribs inside the source structures will be ignited using $300 \mathrm{~mL}$ of n-heptane placed in aluminum pans of known dimensions [7.5" $\times 5$ " $\times 1.4$ " $(19.1 \mathrm{~cm} \times 12.7 \mathrm{~cm} \times 3.6 \mathrm{~cm})]$. Heptane will be ignited using a propane burner (copper tubing and propane cylinder). 


\section{Uncertainties of Measurements}

The measurements of heat fluxes, temperatures, times, wind speed, and distances have uncertainties associated with them. Measurement uncertainties have several components that are primarily grouped into two categories based on the method used to estimate their value. Type A uncertainties are evaluated by statistical methods, and Type B uncertainties are evaluated by other means, often based on scientific judgment using all available relevant information ${ }^{10}$. Type B uncertainties are evaluated by estimating lower and upper limits $a_{-}$ and $a_{+}$, such that the probability that the value lies in the interval $a_{-}$to $a_{+}$is essentially 100 $\%$. If the value is equally probable to lie anywhere within the interval, the best estimate is $\left(a_{+}+a_{-}\right) / 2$, with standard deviation $u_{j}=a / \sqrt{3}$, where $a=\left(a_{+}-a_{-}\right) / 2$. Once all components have been estimated by either Type A or Type B analysis, they are combined using the square root of the sum of the squares (RSS) method to yield the combined standard uncertainty (estimated standard deviation) $u_{c}$. Finally, expanded uncertainties are given by $\pm k u_{c}$, where $k=2$ is the coverage factor for a confidence level of $95 \%$.

Assuming all uncertainties to be symmetric $( \pm)$, following definitions will be used to report uncertainties:

Precision: Uncertainty in the ability of the measurement instrument to resolve information from the sensor.

Bias: Uncertainties from the calibration of the sensor or estimated based on the resolution of the sensor, as well as uncertainties from other known sources of error.

Random error: Uncertainty due to random, unpredictable variations in the measurement process during a typical steady-state period.

The extensive data collection on wind speed will facilitate the evaluation of Type A uncertainties. Most other uncertainties will be Type B, either estimated through scientific judgment or obtained from the literature.

Wind speed uncertainties involve the bidirectional probe design and the measurement statistics from the wind field. Previous studies have suggested that velocities are estimated within $\pm 10 \%$ provided the approach flow direction is within approximately $50^{\circ}$ of the probe axis. Statistical analysis will be carried out for each wind speed level and repeatability will be established by calculating the standard deviation of the average wind speed for each experiment (the average from five probes in the central wind field) from the average wind speed overall. Fluctuation in wind speed measurements due to turbulence will be reflected in the random component calculated by the root-mean-square of the standard deviation of wind speed over all experiments at each wind speed level.

Type $\mathrm{K}$ thermocouples used in this test series have an inherent standard uncertainty of $2{ }^{\circ} \mathrm{C}$ $\left(4^{\circ} \mathrm{F}\right)$ based on the manufacturer's specification. The expanded uncertainty $(95 \%$ confidence interval) with a coverage factor of two is $4{ }^{\circ} \mathrm{C}\left(8^{\circ} \mathrm{F}\right)$. The uncertainty due to $\mathrm{A} / \mathrm{D}$ conversion is an order of magnitude less than this and thus will be neglected.

${ }^{10}$ Taylor BN , Kuyatt CE (1994) Guidelines for evaluating and expressing the uncertainty of NIST measurement results. 
Additional uncertainties in measured temperature are primarily due to radiative heating and cooling of the thermocouple bead that causes it to respond to phenomena other than the surrounding gas temperature. Due to outdoor fire testing, the thermal environment surrounding a given thermocouple is very difficult to characterize. These uncertainties will overwhelm the inherent uncertainties in the thermocouple described earlier.

The main sources of uncertainty pertaining to the total heat flux measurements are: (1) the uncertainty of the A/D conversion, (2) uncertainty in the calibration, and (3) uncertainty due to soot deposition on the sensing surface of the gauge ${ }^{11}$. The uncertainty in $A / D$ conversion is inherent to the data acquisition system. It is system specific and is associated with the digitization of the analog signals from the gauge. This type of uncertainty is taken as negligible. The uncertainty due to soot deposition is more difficult to quantify. The amount of soot deposition depends on many parameters, such as the location of the gauge, the flow field and temperature fields near the gauge, the duration of an experiment, and the soot volume fraction. Quantification of soot effect on heat flux measurements for these experiments will no be considered. Additional uncertainty due to flame impingement on the gauges is considered negligible.

The structure separation distances (SSDs) between the target wall and the shed, distance between bidirectional probes and the shed, distance between the fan and the bidirectional probes, and distance between the shed and heat flux gauge tree will be determined using a tape measure. Sources of uncertainty include the placement of the tape measure and the ability to adjust the positions of shed and bidirectional probes accurately.

Type A uncertainties for mass and moisture measurements in wood cribs will be reported.

\section{Data Management}

The data generated from this project is unique and can be very useful for WUI code development and also for future modeling purposes to better understand fire spread in WUI communities. To facilitate easy availability of data to interested parties, an online repository will be created to store the project description, detailed test plan, test data, instrumentation, calibration and verification reports, safety documents, images, and video clips. A preliminary data management and quality assurance plan is provided elsewhere ${ }^{12}$.

\footnotetext{
${ }^{11}$ A. Maranghides and E.L. Johnsson. Residential Structure Separation Fire Experiments, NIST Technical Note 1600. August 2008.

${ }^{12}$ Structure Separation Experiments Phase 1 Preliminary Test Plan, NIST Technical Note 2161, May 2021, : https://doi.org/10.6028/NIST.TN.2161
} 